\title{
Cimetidine modulates the antigen presenting capacity of dendritic cells from colorectal cancer patients
}

\author{
T Kubota', H Fujiwara*,', Y Ueda', T Itoh', T Yamashita', T Yoshimura', K Okugawa', Y Yamamoto', \\ $\mathbf{Y}$ Yano' and $\mathbf{H}$ Yamagishi'
}

'Department of Digestive Surgery, Kyoto Prefectural University of Medicine, 465 Kajii-cho, Kawaramachi-hirokoji, Kamigyo-ku, Kyoto, 602-084I, Japan

\begin{abstract}
Cimetidine, a $\mathrm{H}_{2}$ receptor antagonist, has been reported to improve survival in gastrointestinal cancer patients. These effects have largely been attributed to the enhancing effects of cimetidine on the host's antitumour cell-mediated immune response, such as inhibition of suppressor $T$ lymphocyte activity, stimulation of natural killer cell activity and increase of interleukin-2 production from helper T lymphocytes. We conducted an in vitro study on the effects of cimetidine on differentiation and antigen presenting capacity of monocyte-derived dendritic cells from advanced colorectal cancer patients and normal controls. As a result, an investigation of expression of surface molecules associated with dendritic cells by flow cytometric analyses showed that cimetidine had no enhancing effect on differentiation of dendritic cells from cancer patients and normal controls. An investigation of $\left[{ }^{3} \mathrm{H}\right]$ thymidine incorporation by allogeneic mixed lymphocyte reactions revealed that cimetidine increased the antigen presenting capacity of dendritic cells from both materials. Moreover, a higher antigen presenting capacity was observed in advanced cancer patients compared to normal controls. These effects might be mediated via specific action of cimetidine and not via $\mathrm{H}_{2}$ receptors because famotidine did not show similar effects. Our results suggest that cimetidine may enhance the host's antitumour cell-mediated immunity by improving the suppressed dendritic cells function of advanced cancer patients.
\end{abstract}

British Journal of Cancer (2002) 86, 1257-126I. DOI: 10.1038/sj/bjc/6600233 www.bjcancer.com

(c) 2002 Cancer Research UK

Keywords: dendritic cell; $\mathrm{H}_{2}$ receptor antagonist; cimetidine; colorectal cancer

Cimetidine, a histamine type $2\left(\mathrm{H}_{2}\right)$ receptor antagonist, widely used to treat peptic ulcers, has also been shown to have clinical benefits in cancer patients. It was first reported in 1988 that a postoperative course of cimetidine improved survival in gastric cancer patients (Tonnesen et al, 1988). Since then, several studies have been published showing major survival advantages in gastrointestinal cancer patients treated with cimetidine (Adams and Morris, 1994; Matsumoto, 1995; Kelly et al, 1999). Many studies on the mechanisms of this action have indicated that the antitumour effects of cimetidine might be due to a direct inhibitory effect on tumour growth (Adams and Morris, 1994; Adams et al, 1994; Reynolds et al, 1996), cell-mediated immunomodulation (Osband et al, 1981; Hellstrand and Hermodsson, 1986; Gifford and Tirberg, 1987), or inhibition of cancer cell metastases (Kobayashi et $a l, 2000)$. The mechanisms proposed for cell-mediated immunomodulation of cimetidine include inhibition of suppressor $\mathrm{T}$ lymphocyte activity (Osband et al, 1981), stimulation of natural killer (NK) cell activity (Hellstrand and Hermodsson, 1986), and increase of interleukin-2 (IL-2) production in helper T lymphocytes (Gifford and Tirberg, 1987).

Dendritic cells (DC), which are potent antigen presenting cells capable of priming naive $\mathrm{T}$ lymphocytes and subsequently inducing cytotoxic $\mathrm{T}$ lymphocytes (CTL) by stimulation of Th1 type immune response, play a central role in cell-mediated immunity (Janeway et al, 1997; Banchereau and Steinman, 1998). With the recent development of culture methods for propagating DC on a

*Correspondence: H Fujiwara; E-mail: hfujj@koto.kpu-m.ac.jp Received I8 December 200I; accepted II February 2002 large scale from human peripheral blood mononuclear cells (PBMC) (Caux et al, 1992; Sallusto and Lanzavecchia, 1994), vaccination aimed at efficient production of CTL with tumour-antigenloaded DC represents a potentially powerful strategy to induce tumour rejection (Young and Inaba, 1996; Nestle et al, 1998). Moreover, since it has also been reported that DC stimulate NK cell activity (Fernandez et al, 1999; Yu et al, 2001), DC should be considered to be associated intimately with not only the production of CTL but also with the whole process of antitumour cellmediated immunity. However, there is little published information regarding the influence of cimetidine on DC function.

Based on the above-mentioned findings, it was reported recently that histamine inhibits the secretion of human interleukin-12 (IL12) via $\mathrm{H}_{2}$ receptors expressed on monocytes (precursors of DC), and these effects of histamine can be reversed by $\mathrm{H}_{2}$ receptor antagonists such as cimetidine (Elenkov et al, 1998; Tineke et al, 1998).

In the present study, we assumed that cimetidine might have some influence on monocyte-derived DC functions via $\mathrm{H}_{2}$ receptors and investigated the effects of cimetidine on in vitro (1) differentiation, (2) antigen presenting capacity, and (3) IL-12 production of monocyte-derived DC from colorectal cancer patients and normal controls.

\section{MATERIALS AND METHODS}

\section{Patients and controls}

The study has been carried out with the ethical committee approval. Ten patients (four men and six women) with advanced 
colorectal cancer, aged 28-65 years (means \pm s.d.; $50.6 \pm 11.5$ years) were studied (Table 1). All tumours were classified as stage IV according to tumour-node-metastasis (TNM). All patients had received chemotherapy and/or operation and had the interval of more than 4 weeks prior to the present study. Their leukocyte numbers were within normal limits. The control subjects consisted of 10 age-matched healthy volunteers (eight men and two women). All patients and all healthy volunteers were free from infection and other complications at the time of study.

\section{Media and reagents}

RPMI 1640 supplemented with $4 \mathrm{mM}$ L-glutamine and $\mathrm{NaHCO}_{3}$ (Nikken, Kyoto, Japan), $100 \mathrm{IU} \mathrm{ml}^{-1}$ penicillin and $100 \mu \mathrm{g} \mathrm{ml}^{-1}$ streptomycin (Sigma, UK), $50 \mu \mathrm{M}$ 2-mercaptoethanol, and $10 \%$ heat-inactivated foetal calf serum (FCS) was used as culture medium throughout the experiments. Human recombinant granulocyte macrophage-colony stimulating factor (GM-CSF) and interleukin-4 (IL-4) were kindly provided by Kirin Brewery (Gunma, Japan) and Genzyme (Minneapolis, MN, USA), respectively. Cimetidine and famotidine were kindly provided by Smith Kline Beecham, Japan (Tokyo, Japan) and Yamanouchi (Tokyo, Japan), respectively.

\section{Generation of DC}

PBMC were obtained from 10 patients with advanced colorectal cancer by leukapheresis using Blood Cell Separator CS-3000 ${ }^{\mathrm{TM}}$ (Baxter, Deerfield, IL, USA) after informed consent was obtained. As control subjects, PBMC from healthy volunteers were prepared by density gradient centrifugation on Ficoll-Hypaque Plus (Pharmacia Biotech, Sweden). Interphases were harvested and washed twice with RPMI 1640 at low speed to remove platelets. Monocytes were separated from these PBMC by plastic dish adhesion for $2 \mathrm{~h}$ at $37^{\circ} \mathrm{C}$ in a $5 \% \mathrm{CO}_{2}$ atmosphere and were further incubated for 7 days at $37^{\circ} \mathrm{C}$ in culture medium supplemented with $500 \mathrm{U} \mathrm{ml}^{-1}$ of GM-CSF and $500 \mathrm{U} \mathrm{ml}^{-1}$ of IL-4. These monocyte-derived DC were used for surface analysis and mixed lymphocyte reaction.

\section{Flow cytometric analyses}

At day 0 of PBMC incubation, 1.0 or $10.0 \mu \mathrm{g} \mathrm{ml}^{-1}$ of cimetidine or 0.1 or $1.0 \mu \mathrm{g} \mathrm{ml}^{-1}$ of famotidine was added to the culture medium, and at day 7, expression of cell surface molecules associated with DC differentiation was analysed using FACScan (Becton Dickinson, Mountain View, CA, USA) and Cell Quest software. The dose of each $\mathrm{H}_{2}$ receptor antagonist $\left(1.0 \mu \mathrm{g} \mathrm{ml}^{-1}\right.$ of cimetidine, $0.1 \mu \mathrm{g} \mathrm{ml}^{-1}$ of famotidine) was based on the $\mathrm{EC}_{50}$, which denotes the serum concentrations of the drug necessary to inhibit the pentagastrin-stimulated secretion of acid by $50 \%$ (Feldman and Burton, 1990). Direct immunofluorescence cell staining

Table I Patient characteristics

\begin{tabular}{lcclll}
\hline $\begin{array}{l}\text { Case } \\
\text { no. }\end{array}$ & $\begin{array}{c}\text { Age } \\
\text { (years old) }\end{array}$ & Sex & Disease & Clinical stage (metastases) \\
\hline I & 57 & F & Rectal cancer & IV & (lung, adrenal gland) \\
2 & 28 & F & Colon cancer & IV & (peritoneum) \\
3 & 56 & M & Rectal cancer & IV & (liver) \\
4 & 42 & F & Colon cancer & IV & (liver) \\
5 & 60 & F & Rectal cancer & IV & (peritoneum) \\
6 & 65 & F & Colon cancer & IV & (liver) \\
7 & 53 & M & Colon cancer & IV & (brain) \\
8 & 60 & M & Colon cancer & IV & (liver) \\
9 & 46 & F & Colon cancer & IV & (ovary, bone) \\
I0 & 39 & M & Colon cancer & IV & (lung) \\
\hline
\end{tabular}

was performed using $\mathrm{PE}$-conjugated anti-CD80 monoclonal antibodies (mAb) (Phar Mingen, San Diego, CA, USA) and PE-conjugated isotype control antibodies (Becton Dickinson, San Jose, CA, USA). Indirect immunofluorescence was performed by staining with unconjugated anti-CD86 mAb (Ancell, Bayport, MN, USA), CR3/43 mAb for HLA-DP/DQ/DR (DAKO A/S, Denmark) and isotype-matched control $\mathrm{mAb}$ followed by PE-conjugated $\mathrm{F}\left(\mathrm{ab}^{\prime}\right)$ two fragments of rabbit anti-mouse IgG/FITC (DAKO A/S, Denmark) as secondary antibody. Ten thousand cells were analysed by flow cytometry and the results were presented as the ratio of the mean channel with cimetidine or famotidine divided by the mean channel without them.

\section{Allogeneic mixed lymphocyte reactions (allo MLR)}

DC of colorectal cancer patients and healthy volunteers were generated from PBMC as described above. Allogeneic T lymphocytes were isolated from PBMC of a single healthy volunteer by nylon fibre non-adherence using $\mathrm{T}$ lymphocyte isolation columns (Nylon Fiber Column T, Wako, Japan). The stimulator cell fractions (DC) were irradiated with $30 \mathrm{~Gy}$. After extensive washing different numbers of stimulators were added to the culture wells containing a fixed amount of $\mathrm{T}$ lymphocytes $\left(10^{5}\right.$ well $\left.^{-1}\right)$ so that the final stimulator to responder ratio (R/S ratio) ranged from 20/1 to $80 / 1$. At day 0 of coculture, $1.0 \mu \mathrm{g} \mathrm{ml}^{-1}$ of cimetidine or $0.1 \mu \mathrm{g} \mathrm{ml}^{-1}$ of famotidine was added to the culture medium. During the last $8 \mathrm{~h}$ of 5 days of culture, $1 \mu \mathrm{Ci}$ well ${ }^{-1}\left[{ }^{3} \mathrm{H}\right]$ thymidine (Amersham Pharmacia Biotech, UK) was added. Cells were then harvested and radioactivity of $\left[{ }^{3} \mathrm{H}\right]$ thymidine was measured with a scintilation counter (Packard, Meriden, CT, USA). The responses of allogeneic $\mathrm{T}$ lymphocytes were expressed as mean radioactivity (c.p.m.) of $\left[{ }^{3} \mathrm{H}\right]$ thymidine incorporated per well. The stimulation index (S.I) was used to quantify the frequency of allogeneic $\mathrm{T}$ lymphocyte proliferation. The S.I was expressed as the ratio of c.p.m. with cimetidine or famotidine to c.p.m. without them.

\section{IL-12 assay}

DC from colorectal cancer patients and healthy volunteers, and allogeneic $\mathrm{T}$ lymphocytes from a single healthy volunteer were cocultured at $\mathrm{R} / \mathrm{S}$ ratio of $10 / 1$ in the presence of $1.0 \mu \mathrm{g} \mathrm{ml}^{-1}$ of cimetidine. After 5 days of culture, supernatants were centrifuged to remove residual cells and stored in $-20^{\circ} \mathrm{C}$ until use. IL-12 p70 heterodimer levels in the supernatants were measured by sandwich type enzyme-linked immunosorbent assay (ELISA) (Immunotech, France) according to the manufacture's instructions. All tests were performed in duplicate. The sensitivity levels of the ELISA assays were $5 \mathrm{pg} \mathrm{ml}^{-1}$.

\section{Statistical analysis}

Results were presented as means \pm standard deviation (s.d.). Student's $t$-test was applied to test significant differences and a $P$ value of $<0.05$ was considered to indicate statistical significance. All tests were two-tailed.

\section{RESULTS}

\section{Effect of cimetidine and famotidine on DC differentiation}

Flow cytometry was used to investigate the effect of cimetidine and famotidine on the differentiation of DC. Expression of MHC-class II, CD80 and CD86 was analysed and viability of differentiated cells was measured.

As a result, no enhancing effect of cimetidine on DC differentiation was found. As shown in Table 2, cimetidine slightly increased the expression of surface molecules only in Case 1, but not in the 
other cases tested. The analysis was stopped in Case 6 because positive data were not found after Case 2. Famotidine showed no effects in any cases tested (data not shown). Similar results were obtained in healthy volunteers (data not shown) or at increasing concentrations (5-, 10-, 50-fold) of each $\mathrm{H}_{2}$ receptor antagonist (data not shown). These results were substantiated by the fact that both cimetidine and famotidine did not enhance the viability of differentiated cells (data not shown).

\section{Effect of cimetidine and famotidine on antigen presenting capacity of DC}

Allo MLR was carried out to investigate the effect of cimetidine and famotidine on the antigen presenting capacity of DC, and $\left[{ }^{3} \mathrm{H}\right]$ thymidine incorporation of allogeneic $\mathrm{T}$ lymphocytes was measured. Monocyte-derived DC generated as described in Materials and Methods were cocultured with allogeneic $\mathrm{T}$ lymphocytes from a single healthy volunteer in the presence of $1.0 \mu \mathrm{g} \mathrm{ml}^{-1}$ cimetidine or $0.1 \mu \mathrm{g} \mathrm{ml}^{-1}$ famotidine.

As a result, in eight out of 10 colorectal cancer patients, cimetidine obviously increased $\left[{ }^{3} \mathrm{H}\right]$ thymidine incorporation of allogeneic $\mathrm{T}$ lymphocytes compared to famotidine (Figure 1). In two typical cases (Case 2 and Case 6), cimetidine increased significantly and constantly $\left[{ }^{3} \mathrm{H}\right]$ thymidine incorporation at each R/S ratio of $20 / 1$ to $80 / 1$ (Figure 2). Moreover, mean S.I of cimetidine at each R/S

Table 2 Effect of cimetidine on DC differentiation

\begin{tabular}{|c|c|c|c|c|c|c|c|}
\hline \multirow[b]{2}{*}{ Case } & \multicolumn{2}{|c|}{ Class II } & \multicolumn{2}{|c|}{ CD80 } & \multicolumn{2}{|c|}{ CD86 } & \multirow[b]{2}{*}{ Enhancement } \\
\hline & $* \mathbf{C} \mathbf{I} .0$ & C 10 & C I.0 & C 10 & C 1.0 & C 10 & \\
\hline I & 1.29 & 1.70 & 1.12 & 1.05 & 1.31 & 2.43 & Yes \\
\hline 2 & 0.59 & 0.85 & 0.94 & 1.01 & 0.88 & 0.87 & No \\
\hline 3 & 1.17 & 0.90 & 0.97 & 0.94 & 1.03 & 1.14 & No \\
\hline 4 & 0.94 & 0.93 & 1.08 & 0.86 & 0.94 & 1.31 & No \\
\hline 5 & 0.96 & 0.99 & 0.77 & 0.82 & 0.88 & 0.70 & No \\
\hline 6 & \multicolumn{2}{|c|}{ ND } & \multicolumn{2}{|c|}{ ND } & \multicolumn{2}{|c|}{ ND } & - \\
\hline 7 & \multicolumn{2}{|c|}{ ND } & \multicolumn{2}{|c|}{ ND } & \multicolumn{2}{|c|}{ ND } & - \\
\hline 8 & \multicolumn{2}{|c|}{ ND } & \multicolumn{2}{|c|}{ ND } & \multicolumn{2}{|c|}{ ND } & - \\
\hline 9 & \multicolumn{2}{|c|}{ ND } & \multicolumn{2}{|c|}{ ND } & \multicolumn{2}{|c|}{ ND } & - \\
\hline 10 & \multicolumn{2}{|c|}{ ND } & \multicolumn{2}{|c|}{ ND } & \multicolumn{2}{|c|}{ ND } & - \\
\hline
\end{tabular}

*C I.0: Cimetidine $1.0 \mu \mathrm{g} \mathrm{ml}^{-1} ; \mathrm{C} 10$ : Cimetidine $10 \mu \mathrm{g} \mathrm{ml}{ }^{-1}$; ND: not done; Mean channel ratio; Mean channel of C 1.0/mean channel of C 0; Mean channel of $C 10$ mean channel of $\mathrm{C} 0$. The expression of MHC-class II, CD80 and CD86 are analysed by flow cytometry. Data are presented as mean channel ratio as described. ratio in all cases was significantly higher than that of famotidine (Figure 3). In a comparison between colorectal cancer patients and normal controls, cimetidine showed higher increases in the former than in the latter $(P=0.048$ at $20 / 1)$ (Figure 4). On the other hand, famotidine did not show any increase both in cancer patients and normal controls (data not shown).

\section{Effect of cimetidine on IL-12 production of DC}

IL-12 concentrations of the supernatants obtained by coculture of $\mathrm{DC}$ with allogeneic $\mathrm{T}$ lymphocytes were measured to evaluate the effect of cimetidine on DC function.

IL-12 production of DC in colorectal cancer patients $(n=7)$ was slightly lower than in normal controls $(n=4)$. However, although cimetidine did not affect IL-12 production of DC in normal controls, it tended to increase IL-12 production in colorectal cancer patients up to the level of normal controls $(P=0.383)$ (Table 3$)$.

\section{DISCUSSION}

The clinical effectiveness of cimetidine against gastrointestinal malignancies has been reported and various mechanisms of action have been proposed. In this study, we discovered for the first time the possibility that cimetidine may increase the antigen presenting capacity of monocyte-derived DC from advanced colorectal cancer patients although it does not enhance their differentiation. These results suggest that cimetidine enhances antitumour cell-mediated immune response by stimulating DC to activate Th1 type immune response and subsequent CTL induction. Gifford and Tirberg (1987) demonstrated that cimetidine increased IL-2 production from mitogen-activated murine spleen cells and this effect might be due to stimulation of helper $\mathrm{T}$ lymphocytes by antigen presenting cells. The present results support their findings.

Our observation that cimetidine increased the antigen presenting capacity of DC from colorectal cancer patients compared to DC from normal controls implies improvement of suppressed DC function in immunosuppressed cancer patients by cimetidine. Dysfunction of DC in advanced cancer patients is predictable and Ninomiya et al (1999) have demonstrated that DC from hepatocellular carcinoma had significantly lower capacity to stimulate allogeneic $\mathrm{T}$ lymphocytes in allo MLR compared to DC from normal controls. The stimulatory effect of cimetidine on $\mathrm{T}$ lymphocytes is well-known (Rocklin, 1976; Gifford et al, 1980), however, it is unlikely that the difference of $\left[{ }^{3} \mathrm{H}\right]$ thymidine incorporation between cancer patients and normal controls is caused
Case 2

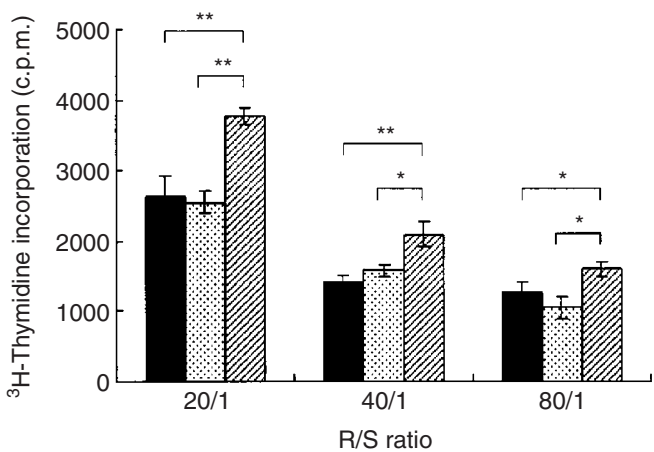

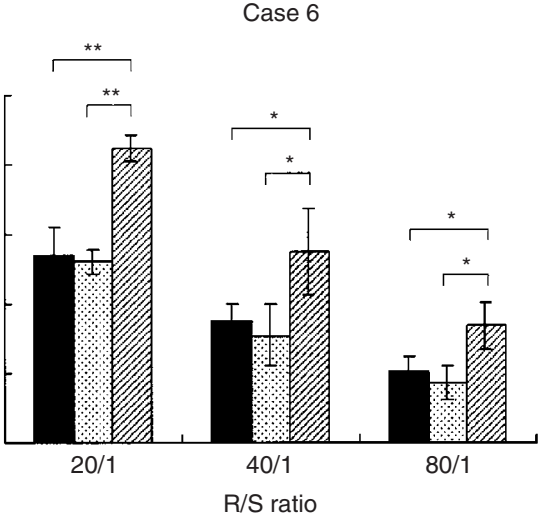

${ }^{*} P<0.05$

${ }^{* *} P<0.01$
Control

Famotidine $0.1 \mu \mathrm{g} \mathrm{m}^{-1}$

Cimetidine $1.0 \mu \mathrm{g} \mathrm{ml}^{-1}$

Figure I Antigen presenting capacity of two typical cases (Case 2 and Case 6). Data are presented as amounts (c.p.m.) of [ $\left.{ }^{3} \mathrm{H}\right]$ thymidine incorporation. 


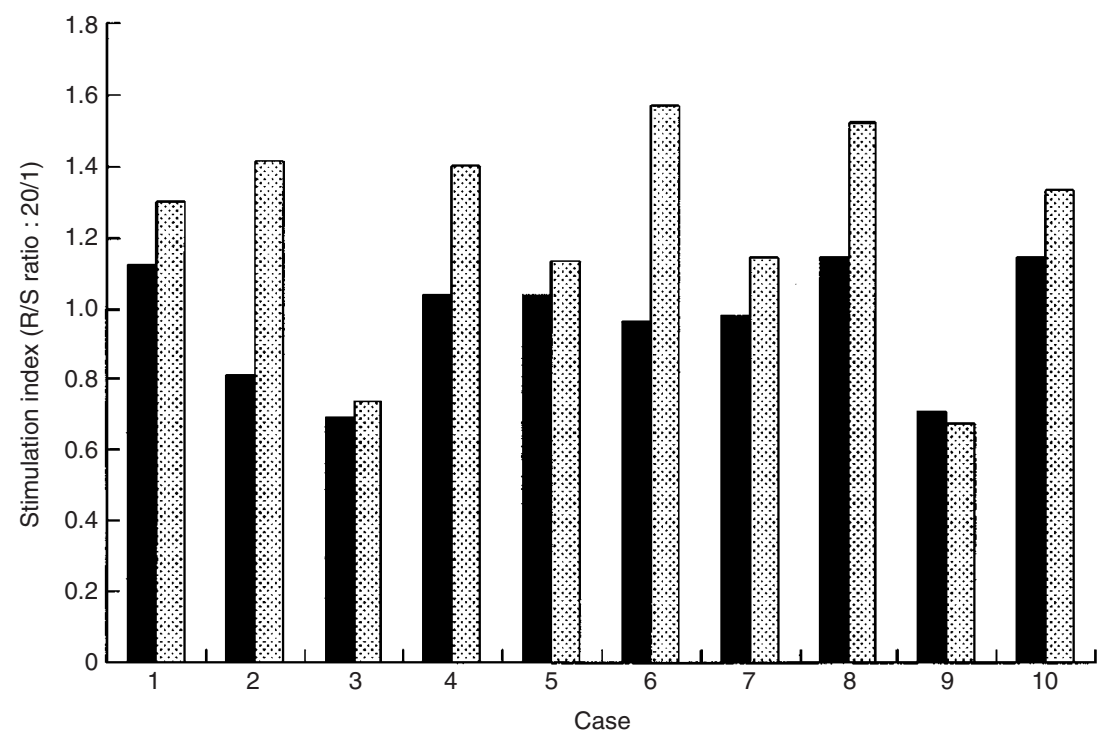

Famotidine $0.1 \mu \mathrm{g} \mathrm{ml}^{-1}$

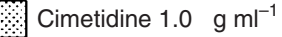

Figure 2 Comparison of S.I of each case with cimetidine and famotidine at R/S ratio of 20/I.

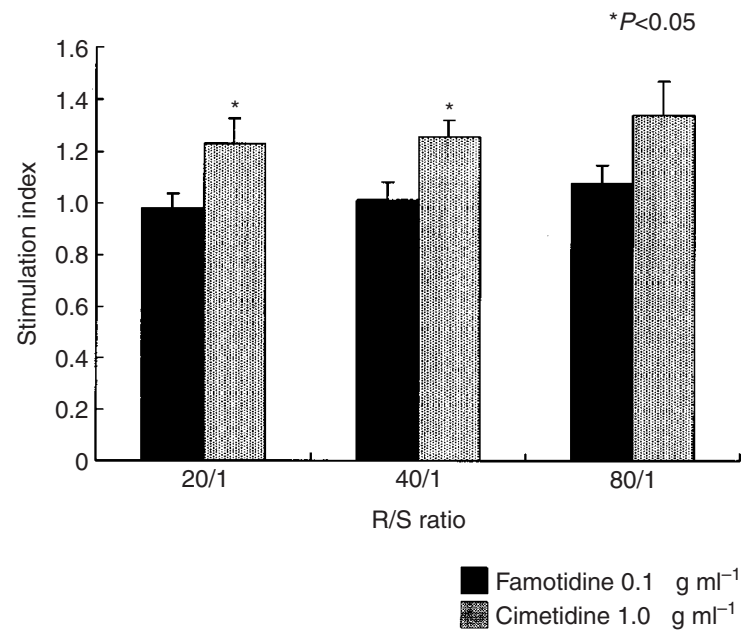

Figure 3 Comparison of mean S.I with cimetidine and famotidine at R/S ratio of $20 / 1 \sim 80 / 1$.

only by the effect of cimetidine on $\mathrm{T}$ lymphocytes because $\mathrm{T}$ lymphocytes from a single healthy volunteer were used as responders in allo MLR.

To confirm the hypothesis that cimetidine gives a direct action to DC themselves and improve the antigen presenting capacity of DC from colorectal cancer patients, we measured IL-12 in the supernatants of allo MLR. IL-12 is well known as a cytokine that is produced by DC responding to antigen stimulation and acts CD4+ helper $\mathrm{T}$ lymphocytes to induce Th1-type immune responses (Banchereau and Steinman, 1998). The present results indicate that IL-12 was produced from DC stimulated by allogeneic $\mathrm{T}$ lymphocytes and cimetidine might improve the suppressed DC function of colorectal cancer patients. Therefore, we conclude that the increase of $\left[{ }^{3} \mathrm{H}\right]$ thymidine incorporation in allo MLR may be due to some effects of cimetidine on not only $\mathrm{T}$ lymphocytes but also DC themselves or the interaction between DC and T lymphocytes.

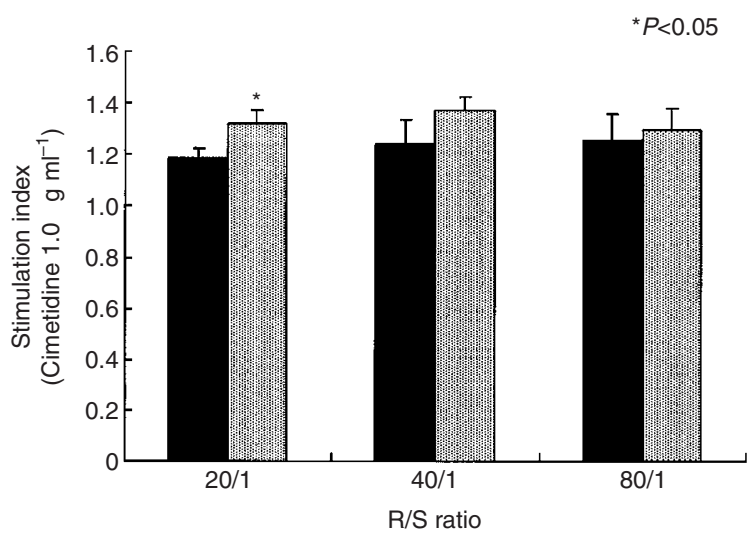

Normal controls

Colorectal cancer patients

Figure 4 Comparison of mean S.I with colorectal cancer patients and normal controls at R/S ratio of $20 / 1 \sim 80 / 1$.

Table 3 IL-12 production by allo MLR

\begin{tabular}{lcc}
\hline & Cimetidine $\left(\mu \mathbf{g ~ m l}^{-\mathbf{I}}\right)$ & $\left.\mathbf{I L - I} \mathbf{( \mathbf { p g ~ m }} \mathbf{~ I}^{-\mathbf{I}}\right)$ \\
\hline Normal controls $(n=4)$ & 0 & $46.7 \pm 1.6$ \\
Colorectal cancer patients $(n=7)$ & 1.0 & $47.5 \pm 3.4$ \\
& 0 & $43.4 \pm 1.7$ \\
\hline
\end{tabular}

Comparison of $\mathrm{IL}-12$ production by all MLR with colorectal cancer patients and normal controls. Data are presented as means \pm s.d.

On the other hand, famotidine, another $\mathrm{H}_{2}$ receptor antagonist, did not show the same effects as cimetidine. Because famotidine behaves as a specific $\mathrm{H}_{2}$ receptor antagonist with a molar potency four to eight times greater than that of cimetidine (Peden et al, 1982; Feldman and Burton, 1990), it is 
natural that famotidine should show equal or greater effects if the effect of cimetidine is mediated via $\mathrm{H}_{2}$ receptors. In this regard, cimetidine has been reported to have better cellmediated immunomodulation (e.g. proliferation and cytotoxicity of lymphocytes) or histamine (or $\mathrm{H}_{2}$ receptor)-dependent inhibitory effects on tumour growth than other $\mathrm{H}_{2}$ receptor antagonists such as famotidine and ranitidine, and the differences between cimetidine and other $\mathrm{H}_{2}$ receptor antagonists might be due to their structures and/or affinities to $\mathrm{H}_{2}$ receptors (Morris and Adams, 1995; Lawson et al, 1996). Kobayashi et al (2000) showed that cimetidine can block the adhesion of colorectal cancer cells to the endothelial cells, suppressing the metastases of cancer cells. They also considered that these actions of cimetidine are not mediated via $\mathrm{H}_{2}$ receptors, because other $\mathrm{H}_{2}$ receptor antagonists, famotidine and ranitidine, did not show a similar effect. While it remains unclear whether $\mathrm{H}_{2}$ receptors are expressed on DC or not,

\section{REFERENCES}

Adams WJ, Morris DL (1994) Short-course cimetidine and survival of patients with colorectal cancer. Lancet 344: 1768-1769

Adams WJ, Lawson JA, Morris DL (1994) Climetidine inhibits in vivo growth of human colon cancer and reverses histamine stimulated in vitro and in vivo growth. Gut 35: $1632-1636$

Banchereau J, Steinman RM (1998) Dendritic cells and the control of immunity. Nature 392: $245-252$

Caux C, Dezutter-Dambuyant C, Schmitt D, Banchereau J (1992) GM-CSF and TNF- $\alpha$ cooperate in the generation of dendritic Langerhans cells. Nature 360: $258-261$

Elenkov IJ, Webster E, Papanicolaou DA, Fleisher TA, Chrousos GP, Wilder RL (1998) Histamine potently suppresses human IL-12 and stimulates IL10 production via $\mathrm{H} 2$ receptors. J Immnol 161: 2586-2593

Feldman M, Burton ME (1990) Histamine 2-receptor antagonists - standard therapy for acid-peptic diseases. $N$ Engl J Med 323: $1672-1680$

Fernandez NC, Lozier A, Flament C, Ricciardi-Castagnori P, Bellet D, Suter M, Perricaudet M, Tursz T, Maraskovsky E, Zitvogel L (1999) Dendritic cells directly trigger NK cell functions; Cross-talk relevant in innate antitumor immune responses in vivo. Nat Med 5: 405-411

Gifford RRM, Hatfield SM, Schmidtke JR (1980) Cimetidine-induced augmentation of human lymphocyte blastogenesis by mitogen, bacterial antigen and alloantigen. Transplantation 29: 143-148

Gifford RRM, Tirberg AF (1987) Histamine type-2 receptor antagonist immune modulation II. Cimetidine and ranitidine increase interleukin-2 production. Surgery 102: $242-247$

Hellstrand K, Hermodsson S (1986) Histamine H2-receptor-mediated regulation of human natural killer cell activity. J Immunol 137: 656-660

Janeway CA, Travers P, Hunt S, Walport M (eds) (1997) Immunobiology The immune system in health and disease, 3rd edn London: Current Biology Ltd.

Kelly MD, King J, Cherian M, Dwerryhouse SJ, Finlay IG, Adams WJ, King DW, Lubowski DZ, Morris DL (1999) Randomized trial of preoperative cimetidine in patients with colorectal carcinoma with quantitative assessment of tumor-associated lymphocytes. Cancer (Phila.) 85: 1658-1663

Kobayashi K, Matsumoto S, Morishita T, Kawabe T, Okamoto T (2000) Cimetidine inhibits cancer cell adhesion to endothelial cells and prevents metastasis by blocking E-selectin expression. Cancer Res 60: 3978-3984

Lawson JA, Adams WJ, Morris DL (1996) Ranitidine and cimetidine differ in their in vitro and in vivo effects on human colonic cancer growth. $\mathrm{Br} J$ Cancer 73: $872-876$

Matsumoto S (1995) Cimetidine and survival with colorectal cancer. Lancet 346: 115 the effect of cimetidine on the antigen presenting capacity of DC appears to arise because of cimetidine-specific actions.

Although it remains unclear whether or not the modulating effects of cimetidine on DC function observed in our investigation in vitro have clinically substantial meanings, clinical effectiveness of cimetidine against gastrointestinal malignancies are considered to be due to the total of immunological and non-immunological actions of cimetidine.

Finally, both tumour-antigen-specific and non-specific immunosuppression have been observed in the tumour-bearing host (Roth, 1983; Ninomiya et al, 1999). Therefore, immunostimulation offers theoretical benefits for immunotherapy. Further investigation into DC functions is promising in the search for more clinically effective tumour-antigen-specific immunotherapy and also for the elucidation, of immunosuppressive mechanisms in tumour-bearing hosts.

Morris DL, Adams WJ (1995) Cimetidine and colorectal cancer - old drug, new use? Nat Med 1: $1243-1244$

Nestle FO, Alijagic S, Gilliet M, Sun Y, Grabbe S, Dummer R, Burg G, Schadendorf D (1998) Vaccination of melanoma patients with peptide- or tumor lysate-pulsed dendritic cells. Nat Med 4: 328-332

Ninomiya T, Akbar SMF, Masumoto T, Horiike N, Onji M (1999) Dendritic cells with immature phenotype and defective function in the peripheral blood from patients with hepatocellular carcinoma. J Hepatol 31: 323-331

Osband ME, Hamilton D, Shen Y-J, Cohen E, Shlesinger M, Laven P, Brown A, McCaffrey R (1981) Successful tumour immunotherapy with cimetidine in mice. Lancet 1: $636-638$

Peden NR, Robertson AJ, Boyd EJS, Brown RA, Gibbs JH, Potts RC, Wormsley KG, Beck JS (1982) Mitogen stimulation of peripheral blood lymphocytes of duodenal ulcer patients during treatment with cimetidine or ranitidine. Gut 23: 398-403

Reynolds JL, Akhter J, Morris DL (1996) In vitro effect of histamine and H1 and $\mathrm{H} 2$ receptor antagonists on cellular proliferation of human malignant melanoma cell lines. Melanoma Res 6: 95-99

Rocklin RE (1976) Modulation of cellular-immune responses in vivo and in vitro by histamine receptor-bearing lymphocytes. J Clin Invest 57: 1051 1058

Roth JA (1983) Tumor induced immunosuppression. Surg Gynecol Obstet 156: $233-240$

Sallusto F, Lanzavecchia A (1994) Efficient presentation of soluble antigen by cultured human dendritic cells is maintained by granulocyte/macrophage colony-stimulating factor plus interleukin-4 and down regulated by tumor necrosis factor alpha. J Exp Med 179: 1109-1118

Tineke CTM, van der Pouw Kraan TC, Snijder A, Boeije LCM, de Groot ER, Alewijnse AE, Leurs R, Aarden LA (1998) Histamine inhibits the production of interleukin-12 through interaction with $\mathrm{H} 2$ receptors. J Clin Invest 102: $1866-1873$

Tonnesen T, Knnige U, Bulow S, Bulow S, Damm P, Fischerman K, Hesselfeldt, Hjortrup A, Pedersen IK, Pedersen VM, Siemssen OJ, Svendsen LB, Chrischansen PM (1988) Effect of cimetidine on survival after gastric cancer. Lancet 2: 990-991

Young JW, Inaba K (1996) Dendritic cells as adjuvants for class I major istocompatibility complex-restricted antitumor immunity. J Exp Med 183: 7 11

Yu Y, Hagihara M, Ando K, Gansuvd B, Matsuzawa H, Tsuchiya T, Ueda Y, Inoue H, Hotta T, Kato S (2001) Enhancement of human cord CD34 $4^{+}$cellderived NK cell cytotoxicity by dendritic cells. J Immunol 166: 1590 - 1600 